This is a peer-reviewed, accepted author manuscript of the following research article: Garanti, Z., \& Berjozkina, G. (2021). Introduction: what are the challenges and opportunities for tourism sustainability in Cyprus? Worldwide Hospitality and Tourism Themes, 13(6), 691-696. https://doi.org/10.1108/WHATT-07-2021-0103

\title{
Introduction: What are the challenges and opportunities for tourism sustainability in Cyprus?
}

\author{
Zanete Garanti \\ Department of Business Administration, City Unity College Nicosia, Nicosia, Cyprus \\ Galina Berjozkina \\ Department of Hospitality and Tourism, City Unity College Nicosia, Nicosia, Cyprus
}

\begin{abstract}
Purpose - This paper aims to provide an overview and the context of this theme issue. The paper sheds light on the theme issue articles that deal with the strategic question exploring challenges and opportunities for sustainable tourism development in Cyprus.

Design/methodology/approach - This paper outlines the theme issue approach to explore challenges and opportunities for sustainable tourism development in Cyprus. The strategic question is tackled in a series of papers in the form of literature review, review of data and evidence, interactions with practitioners and practical solutions articles.

Findings - The findings of the theme issue focus on sustainability challenges and opportunities in Cyprus and provide insights into the history, current state and progress of implementation of sustainable development in the tourism and hospitality industry.

Originality/value - This theme issue outlines the challenges that the tourism industry faces in a small island state, highly depending on income generated by conventional tourism activity. In turbulent times where all stakeholders actively demand more sustainable, balanced tourism activity, articles in this theme issue provide insights into stakeholder involvement, support availability, residents' perceptions towards tourism activity, as well as opportunities to develop innovative, technologically advanced solutions, thematic tourism activities in remote regions and destinations, and implement sustainability concepts in tourism and hospitality education.
\end{abstract}

Keywords - sustainability, challenges, opportunities, tourism, hospitality, Cyprus

Paper type -Viewpoint

\section{The global context}

The concept of sustainable development first evolved in the 1970s, and since then, has been a dominant global development paradigm, nevertheless, very controversial (Sharpley, 2020). From a broad perspective, sustainability consists of three pillars: economic, social and environmental. A comprehensive definition of tourism sustainability is proposed by Asmelash and Kumar (2019), stating that system (destination) sustainability is a synergy between the human system, with three sustainability dimensions of economic, socio-cultural and institutional, and ecosystem, which is an environmental sustainability dimension.

Several authors have discussed the ambiguity of defining, achieving, measuring sustainability. For example, in the recent publication by Zhang et al. (2021), a comprehensive framework of destination sustainability in the sharing economy is proposed. First, it outlines five important stakeholders representing the human capital in the destination: tourists, sharing economy platforms, government, tourism enterprises and residents. Secondly, stakeholders' critical resources, reflecting natural and manufactured capital, are listed, respectively: money, time and involvement; online platforms; legislative and public resources; staged authenticity; authentic 
resources. Then, intangible assets, also called social capital, provided by stakeholders are identified: comments and feedback; information synergy; management and regulation; knowledge-based assets; authenticity co-creation. Therefore, it can be concluded that destination sustainability is aggregation and synergies between human, natural, manufactured and social capital.

Similarly, Hall (2019) emphasises the heterogeneity of tourism sustainability, pointing out that sustainability at its core is an environmental issue. Still, it is personal, managerial, policy, economic responses that frame the convolution of sustainability. Theme issue editors and the writing team aim to capture the complexity of the tourism and destination sustainability in this theme issue, researching sustainability challenges and opportunities from various perspectives.

\section{The Cyprus context}

Cyprus island is a famous sun and sea tourist destination in the Mediterranean region, experiencing rapid growth over the past decades. According to the Statistical Service of Cyprus (2021), almost 4 million tourists visited Cyprus in 2019, a country that has just over 1 million inhabitants. Moreover, tourism activity has been multiplying- tourist arrivals have doubled since 2010 and are over 11 times higher than in the 1980s. Overall, travel and tourism contributed 23\% of GDP in Cyprus in 2019, which is significantly higher than the average of $4 \%$ in EU countries. In addition, the tourism industry in Cyprus provides 115 thousand jobs.

Tourism activity has a significant role in the economic development of Cyprus. However, heavy tourism activity, concentrated in the coastal zones, overcrowding and over-tourism during the summer season, followed by low activity levels in the low season, creates tremendous economic, social, cultural, political and environmental challenges (Insch, 2020; Walker et al., 2020). In tourism destinations like Cyprus, sustainability is necessary rather than optional (Twining-Ward $\&$ Butler, 2002). Nevertheless, the tourism industry is known to address the challenges at a low pace, creating a gap between theoretical and practical sustainability (Mihalic, 2020). Sustainability in small island states can only be achieved if it benefits the local community, local economy and is ecologically sustainable (Sirakaya et al., 2011), approaching the use of resources today in the way it is preserved for future generations.

For small island states dealing with the new sustainability agenda proposed by international and national organisations like the UNWTO and EU, tour operators, customers, residents, and other stakeholders (Sigala, 2008; Bichler, 2019; Durán-Román et al., 2021) is particularly difficult. Small islands often suffer from diseconomies of scale (Weaver, 2017), have limited access and availability of resources to plan and develop sustainable tourism, and are very vulnerable to hazards (Kennedy et al., 2020). Lack of resources and capacity to undertake significant investment projects and implement changes towards a more sustainable tourism industry leaves small island states like Cyprus lagging behind other EU countries.

A significant drop in tourism activity due to Covid-19 left Cyprus struggling from lack of tourists and tourism-related income. However, researchers suggest that the time of lockdowns and travel restrictions is an excellent opportunity to overthink tourism and implement long-delayed changes (Sharma et al., 2021; Haywood, 2020). Thus, there is no moving back to old normal. Instead, tourism activity worldwide has to move towards a new normal: a more sustainable, resilient and inclusive activity, tackling the developmental goals developed by UNWTO and beyond. Therefore, developing this theme issue in 2020 and 2021 seems to be the turning point of tourism sustainability in Cyprus, which gives theme issue editors and the writing team a great pleasure and 
responsibility to present the articles dealing with opportunities and challenges of tourism sustainability in Cyprus.

\section{Design of the theme issue}

In this theme issue, we address some of the main challenges for the tourism industry's social, economic and environmental sustainability in Cyprus. In light of the recent developments, we selected a series of contributions, from literature review to review of data and evidence to interactions with practitioners and practical solutions for this particular theme issue. This issue's multidisciplinary and multicultural writing team ensures that the tourism industry and its sustainability in Cyprus are discussed from various perspectives and viewpoints.

The issue is opened with a thematic literature review on the main challenges faced in the countries that highly depend on tourism activity, like Cyprus, where almost one-fourth of the GDP is generated by tourism activity. Some of the main challenges indicated by the authors Dembrovska and Zvaigzne (2021) are economic (tackling seasonality and leakage of economic benefits, balancing tourism activity throughout the year), social (sustaining locality, culture, customs and traditions without commercialising and adapting to the needs of tourists), and environmental (marine, natural environment, animals, species, biodiversity).

The following thematic literature review presents different levels and types of stakeholders involved in the planning and implementing sustainable tourism in Cyprus. Although Cyprus is a relatively small country, it is characterised by a complex structure of stakeholders contributing to sustainable tourism development. Authors Katemliadis and Markatos (2021) have classified international, local and individual levels of stakeholders, showing the specific role and tasks.

The following article in the theme issue is a review of data and evidence by Violaris and Charalambous (2021), where authors outline support for economic, social and environmental tourism industry development in Cyprus. Although implementing sustainability measures brings financial benefits to organisations in the long term, the availability of EU funding is a critical factor for tourism businesses to consider becoming more sustainable.

Residents being one of the main stakeholders of tourism activity, following article by Liasidou et al. (2021) study residents' and their perception of what environmental and social impact tourism activity has on the rural areas in Cyprus. Residents' mainly see tourism activity as a driver of growth and development. However, several challenges and threats are also identified.

With the growth of tourism activity in Cyprus, many institutions, both public and private, university and non-university type emerged in Cyprus in recent decades, providing tourism education and preparing the future managers and practitioners to support the industry's growth. Berjozkina and Melanthiou (2021) examine to what extent the sustainability concept is implemented in higher education programs at the Bachelor level, preparing students to be future professionals who can initiate sustainable changes in the organisations.

A complex system of stakeholders manages sustainable tourism development in Cyprus. However, Cyprus Sustainable Tourism Initiative (CSTI) is one of the most active independent organisations having international recognition, aiming towards sustainable tourism development in Cyprus and linking multiple stakeholders in one network. In an article by Kolongou et al. (2021), the role of CSTI in implementing and rising sustainability standards is explored.

Although Cyprus was successfully managed as a sun and sea destination, destination management organisations and stakeholders have recognised the importance of a more sustainable approach. In June 2021, public officials presented the new Love Cyprus brand. Rebranding efforts aim to attract tourists to various experiences throughout the year, refocusing tourism activity from sun and sea 
to spa, mountain, wedding, nature experiences, etc. Although rebranding Cyprus is a recent effort, in an article by Litavniece et al. (2021) on Under-tourism regions and destinations: what are their opportunities to succeed? Rural destinations' efforts to create meaningful tourism experiences since 2003 are explored. By studying cases of two rural villages, the authors of the article propose nine success factors explaining how thematic experiences can be created.

The final article in the theme issue by Berjozkina and Karami (2021) explores the emerging field and opportunities that 3D printing can provide in concrete/ building printing, restoration of cultural heritage, souvenir printing and food printing. In addition, added manufacturing can become a tool to improve sustainability through materials, design, production processes and final product.

\section{Conclusions}

The strategic question of the issue was: What are the challenges and opportunities for tourism sustainability in Cyprus?. The articles that were included in the issue provide an overview of sustainable tourism in Cyprus and its' opportunities.

The comprehensive and diverse overviews of contributing authors provide us with insights and trends of sustainability in Cyprus in various sectors of tourism, such as the economic, social, environmental sectors, stakeholders' and industry practitioner's involvement in sustainable development, resident's perception, undertourism regions, education and technology.

The central theme of the issue was focused on sustainable tourism in Cyprus. We can see that Cyprus is still facing challenges in moving towards sustainability as some sectors have a grooving demand and opportunity for a better change. This is the main reason why more detailed attention needs to be moved towards sustainability issues in Cyprus.

In order to get Cyprus to the top place for sustainable destination among other European countries, some policies need to be implemented in the sector of tourism. It can be done by continuously exploring new trends in sustainable tourism and updating.

Currently, the tourism sector in Cyprus is facing challenges due to Covid-19, like every other tourist-centred country. More people nowadays prefer to travel to sustainable destinations and make sure that this destination is safe. For the island to successfully pass the challenges related to recent worldwide events, it needs to be more sustainable and responsible when it comes to tourism. Finally, it can be said that sustainability can become a factor for the competitiveness and attractiveness of Cyprus on an international level because sustainability is a trend and a responsible way of spending holidays.

\section{References}

Asmelash, A.G. and Kumar, S., 2019. Assessing progress of tourism sustainability: Developing and validating sustainability indicators. Tourism Management, 71, pp.67-83.

Bichler, B.F., 2019. Designing tourism governance: The role of local residents. Journal of Destination Marketing \& Management, p.100389.

Durán-Román, J.L., Cárdenas-García, P.J. and Pulido-Fernández, J.I., 2021. Tourists' willingness to pay to improve sustainability and experience at destination. Journal of Destination Marketing \& Management, 19, p.100540.

Hall, C.M., 2019. Constructing sustainable tourism development: The 2030 agenda and the managerial ecology of sustainable tourism. Journal of Sustainable Tourism, 27(7), pp.1044-1060. Haywood, K.M., 2020. A post COVID-19 future-tourism re-imagined and re-enabled. Tourism

Geographies,

Statistical
Service
22(3),

Cyprus
(2021). pp.599-609. 
https://www.mof.gov.cy/mof/cystat/statistics.nsf/services_71main_en/services_71main_en?Open Form\&sub $=1 \&$ sel $=1$

Insch, A., 2020. The challenges of over-tourism facing New Zealand: Risks and responses. Journal of Destination Marketing \& Management, 15, p.100378.

Kennedy, V., Crawford, K.R., Main, G., Gauci, R. and Schembri, J.A., 2020. Stakeholder's (natural) hazard awareness and vulnerability of small island tourism destinations: a case study of Malta. Tourism Recreation Research, pp.1-17.

Mihalic, T., 2020. Concpetualising overtourism: A sustainability approach. Annals of Tourism Research, 84, p.103025.

Sharma, G.D., Thomas, A. and Paul, J., 2021. Reviving tourism industry post-COVID-19: A resilience-based framework. Tourism management perspectives, 37, p.100786.

Sharpley, R., 2020. Tourism, sustainable development and the theoretical divide: 20 years on. Journal of Sustainable Tourism, 28(11), pp.1932-1946.

Sigala, M., 2008. A supply chain management approach for investigating the role of tour operators on sustainable tourism: the case of TUI. Journal of cleaner production, 16(15), pp.1589-1599.

Sirakaya, E., Jamal, T.B. and Choi, H.S., 2001. Developing indicators for destination sustainability. The encyclopedia of ecotourism, pp.411-432.

Twining-Ward, L. and Butler, R., 2002. Implementing STD on a small island: Development and use of sustainable tourism development indicators in Samoa. Journal of sustainable tourism, 10(5), pp.363-387.

Walker, T., Lee, T.J. and Li, X., 2021. Sustainable development for small island tourism: developing slow tourism in the Caribbean. Journal of Travel \& Tourism Marketing, 38(1), pp.115.

Weaver, D.B., 2017. Core-periphery relationships and the sustainability paradox of small island tourism. Tourism Recreation Research, 42(1), pp.11-21.

Zhang, H., Leung, X.Y. and Bai, B., 2021. Destination sustainability in the sharing economy: a conceptual framework applying the capital theory approach. Current Issues in Tourism, pp.1-18. 